\title{
Seeds of Trust. Italy's Gruppi di Acquisto Solidale (Solidarity Purchase Groups)
}

\author{
Cristina Grasseni ${ }^{1}$ \\ University of Utrecht, the Netherlands
}

\begin{abstract}
This article presents a case study of the solidarity economy in Italy: the Italian G.A.S. - Gruppi di Acquisto Solidale, which I translate as Solidarity Purchase Groups. GAS are often conceptualized as "alternative food networks". Beyond this categorization, I highlight their novelty in relational, political, and ecological terms, with respect to their capacity to forge new partnerships between consumers and producers. Introducing an ethnographic study that I have developed in a recent monograph (Grasseni 2013), I dwell here in particular on how the solidarity economy is embedded in practice. I argue that gasistas' provisioning activism is something different to mere "ethical consumerism." Activists use the notion of "co-production" to describe their engagement as a concurrent rethinking of the social, economic, and ecological aspects of provisioning. Building also on a quantitative survey of the GAS movement in northern Italy, I pursue an ethnographic understanding of "co-production." I argue that producers and consumers in GAS networks "co-produce" both economic value and ecological knowledge, while re-embedding their provisioning practice in mutuality and relationality.
\end{abstract}

Keywords: Solidarity economy, solidarity purchase groups, Gruppi di Acquisto Solidale, alternative food networks, provisioning, co-production, Gibson-Graham, Italy.

\section{Résumé}

Cet article présente une étude de cas de l'économie solidaire en Italie: le G.A.S. italien - Gruppi di Acquisto Solidale, que je traduis comme les groupes de solidarité d'achat. G.A.S. sont souvent conceptualisée comme «réseaux alimentaires alternatifs». Au-delà de cette catégorisation, je souligne la nouveauté en termes relationnels , politiques et écologiques , par rapport à leur capacité à forger de nouveaux partenariats entre les consommateurs et les producteurs. Je présente une étude ethnographique que j'ai développé dans une monographie récente (Grasseni 2013), et je me concentre sur la façon dont l'économie solidaire est intégré dans la pratique. Je soutiens que l'approvisionnement de l'activisme de gasistas n'est pas la même chose que «la consommation éthique». Les militants utilisent la notion de «co- production» pour décrire leur engagement comme une remise en question des aspects sociaux, économiques et écologiques de l'approvisionnement. En s'appuyant également sur une enquête quantitative du mouvement de G.A.S. dans le nord de l'Italie, je poursuis une compréhension ethnographique de «co- production». Je soutiens que les producteurs et les consommateurs dans les réseaux G.A.S. «co- produire» à la fois une valeur économique et les connaissances écologiques, tout en reembedding leur approvisionnement alimentaire dans la réciprocité et relationnalité.

Mots-clés: Economie solidaire, les groupes d'achat solidaires, Gruppi di Acquisto Solidale, réseaux alimentaires alternatifs, l'approvisionnement, la co- production, Gibson-Graham, l' Italie.

\section{Resumen}

Este artículo presenta un caso de estudio de economía solidaria en Italia: el G.A.S. italiano -Gruppi di Acquisto Solidale, el cual traduzco como Grupos de Compra Solidaria (Sodarity Purchase Groups). GAS son frecuentemente conceptualizadas como "redes de comida alternativa". Más allá de esta categorización, deseo resaltar su novedad en términos relacionales, políticos, y económicos, con respecto a su capacidad de forjar nuevas sociedades entre consumidores y productores. Introduciendo un estudio etnográfico que he

\footnotetext{
1 Dr. Cristina Grasseni, Associate Professor, Department of Cultural Anthropology, University of Utrecht, the Netherlands. Email: crisgrasseni "at" gmail.com. I thank Boone Shear and Brian Burke for their insightful and inspirational comments on the paper I gave at the 2011 Meeting of the Society for Applied Anthropology, from which this article was developed. More recent ethnography on GAS was partly funded by the Wenner Gren Foundation for Anthropological Research (Post-Ph.D. Research Grant "Seeds of Trust"). This is the fourth paper in Burke, B.J. and B.W. Shear (eds.) 2014. "Non-capitalist political ecologies", special section of the Journal of Political Ecology 21: 127-221.
} 
desarrollado en una monografía reciente (Gasseni 2013), enfatizo en particular en cómo la economía solidaria es llevada a cabo en la práctica. Argumento que el activismo provisionado por gasistas es algo diferente al mero "consumismo ético". Los activistas usan la noción de "co-producción" para describir su compromiso con un replanteamiento concurrente de los aspectos sociales, económicos, y ecológicos de aprovisionamiento. Con base también en un estudio cuantitativo del movimiento GAS en el norte de Italia, busco un entendimiento etnográfico de de "co-producción". Argumento que productores y consumidores en las redes GAS "co-producen" valores económicos y conocimiento ecológico, mientras re-formulan sus prácticas de aprovisionamiento en mutualidad y relacionalidad.

Palabras clave: Economía solidaria, grupos de compra solidaria, Gruppi di Acquisto Solidale, redes de comida alternativa, aprovisionamiento, co-producción, Gibson-Graham, Italia.

\section{Solidarity in practice: Italy's solidarity purchase groups}

Amid concerns about climate change and an unresolved financial crisis, Europeans are experimenting with a range of collective practices of food provisioning. A rich constellation of grassroots movements are posing the question of food as a political object of collective deliberation, and they are devising and organizing alternative food provisioning networks that value health and quality standards, but also social and environmental sustainability. Across the urban western world, alternative provisioning comprises a wide range of formulas. The Transition movement stemming from Ireland places emphasis on energy production and consumption; the French AMAPs, Associations for the Preservation of Peasant Agriculture, encourage advance planning and financial support to local crops (Lamine and Perrot 2008); and in the US, community supported agriculture has brought direct farmer-consumer links to a high level of functional organization and market visibility, especially through commercial digital networks such as Just Food for New York City or Local Harvest nationwide. ${ }^{2}$ In Italy diverse public responses to the issue of sustainability are emerging, from Slow Food (Siniscalchi 2013) to Transition Towns and the Degrowth movement (Martinez-Alier et al. 2014). Each activist circle underlines particular aspects of this critical moment and their proposal for a reinvention of society through a radical rethinking of the economy and the ecology of capitalist consumption: degrowth theory critiques the idea of sustainable growth, ethical finance responds to the deadly loops of capitalism "dumping" ecologic and social costs on the most disenfranchised, while "zero-mile democracy" proposes to rethink the political fabric of society through a defense of the commons and a reconstruction of short supply chains. ${ }^{3}$

Slow Food has also recently embraced a more engaged stance towards a Good, Clean, and Fair food. With the publication of his Slow Food Nation, in 2007, originally published in Italian as Buono, Pulito e Giusto in 2005, the founder of Slow Food Carlo Petrini made a conscious political move to change the Slow Food identity from what is widely perceived as a hedonistic association of "Foodies" to that of a movement, positively set to address the poverty of the very ones who produce food (Petrini 2007). I was present at the 2010 National Assembly of the Slow Food Association, whose manifesto was tellingly entitled The consequences of pleasure (Slow Food Italia 2010). Slow Food was taking the responsibility of addressing not only the gastronomic aspect of valuing traditional recipes, supporting artisanal food production and smallscale farming, but also other key aspects of the production chain so that once "good and clean" food is produced, it exchanges hands in a "just" way, too. In doing so, Petrini explicitly promoted the international role played by Slow Food and endorsed another Italian model, an openly political form of food activism: the GAS, or Solidarity Purchase Groups.

Especially in northern Italy, where post-industrial economies interact and merge with the re-invention of local foods through the lens of a heritage framework (Grasseni 2011, 2012), GAS are moving beyond this paradigm, establishing new types of "social networks" that involve producers and consumers in what they

\footnotetext{
2 Just Food: http://www.justfood.org. Local Harvest: http://www.localharvest.org. For a critical examination of CSAs, their limits and potentials, see DeLind (1999, 2002), Hinrichs (2003), and Hinrichs and Lyson (2009).

3 There is no space here for a comprehensive review of the complex European context of alternative provisioning networks. Here are useful links to some of the most representative circles on degrowth, ethical finance, and "the republic of the commons": www.degrowth.org; http://www.finansol.it/?author=1 and www.democraziakmzero.org.
} 
call "co-production". This consists of various forms of food re-localization, creating new economic circuits, favoring short supply chains, and supporting local agriculture. I argue that this type of provisioning activism fosters active citizenship and re-embeds the economy in relationships of trust (Grasseni 2013).

GAS practice introduces a novel element to the debate about "alternative food networks", in that they veritably re-invent everyday provisioning in collective and participatory ways. They are grassroots aggregations of consumers who involve producers in direct and collective transactions. GAS mainly organize food provisioning but, increasingly, non-food provisioning too (of clothes, shoes, cleaning materials, and in some experimental cases also electricity, car insurance, dental care, and telecommunication). The first Solidarity Purchase Group dates back to 1994. The current economic crisis has made their formula of collective bulk-buying from trusted and local producers quite popular, shifting an estimated 80 million euros (US\$110 million) away from large distribution (L'Eco di Bergamo 2012). Gasistas - as GAS members call themselves - manage the various practical aspects of direct provisioning on a voluntary basis. They often organize themselves in groups of neighboring families, who hold regular meetings to select their providers and organize logistics. By creating new direct producer/consumer economic circuits, they wish to responsibly collaborate with the farmers, enabling them to conduct an economically viable business, but also negotiating quality criteria and encouraging "conversions" to organic farming. ${ }^{4}$

In their support for quality farming, Solidarity Purchase Groups are similar to community-supported agriculture in the US. Nevertheless, they differ for their collective modus operandi. GAS not only make collective orders to a range of farmers, but they organize this activity through regular meetings and, crucially, voluntary work. Every group member is expected to actively participate in the running of the GAS, usually through the rule that each gasista acts as a "product referent" for one or more items. A "referent" liaises with the provider, negotiates the price, gathers the gasistas wish-list, prepares a spreadsheet, pays up and collects the order from the provider (or arranges for delivery if too far to pick up the order herself). She usually hosts deliveries at her home for the other gasistas to come, pay their dues and collect their share. These reciprocal visits may be hurried, with the car parked outside with hazard lights flashing, or ideally relaxed and convivial, with the offer of a cup of coffee by the host and reciprocal catching up with gossip. In my experience, the majority of gasistas participating in the monthly meetings were female (with only two husbands accompanying them), but deliveries and pick-ups were shared within families. I might send my husband to pick up the meat, or find a gasista's son or daughter overseeing their mother's olive oil deliveries.

GAS tend to be groups of 20-40 families, but there are many ways of setting up a Solidarity Purchase Group. I have known neighborhood-groups of just eight families, and GAS of up to 150 families, organized in subgroups or "chains" (catene) of 13 to 21 families. Crucially, GAS pay their trusted providers higher prices than they would receive from large distribution networks. The farmers may be "marginal" in many ways: they may be practicing organic farming without certification (because they cannot afford the bureaucratic costs of certification), or may be ageing local farmers, or neo-rural young entrepreneurs. It is up to each Solidarity Purchase Group to interpret how to practice "solidarity" with the producers, among themselves, and with the environment. Documentation is plentiful on the GAS website (www.retegas.org), but registration with the national network is not mandatory and no form of hierarchy is implemented. In other words, the National Charter functions as a kind of constitutional statement, which presents a number of foundational ideals and principles, such as respect for the environment and solidarity, but each group is free to develop their own practical procedures. Thus, each GAS is self-governed by its assembly. In time, local networks of GAS have developed. In the Bergamo area, since 2009 more than thirty Solidarity Purchase Groups have joined ReteGasBergamo, but about double that number exist in total. There is a nationwide website, a listserv and a national yearly assembly, but none of these operate on the basis of formal delegation or through a hierarchy of representatives. Thus GAS are accountable purely in moral terms to each other and to the assembly.

Each GAS establishes its own practical routines and through those, solidarity criteria are established on a strictly local basis, so that some groups may opt for further choices of voluntary simplicity, for

\footnotetext{
${ }^{4}$ For an analysis of gasista discourse and its preferential use of metaphors that convey the sense of regeneration and birth, both from botany and the animal world, see Grasseni (2013).
} 
supporting local short food chains, or for setting up a time bank. For some GAS, priority goes to organic farming. For others, supporting proximal and small farmers is more important, even if not organic. Often GAS collaborate with local Fair Trade shops, and sometimes with socially inclusive agricultural cooperatives. The main idea is to re-localize provisioning to decrease one's ecological footprint but also to regain direct control of the supply chain - to the advantage of transparent pricing and socially acceptable conditions of labor for all those involved (Gesualdi 1990; Laville 1994; Saroldi 2001). By harnessing the power of collective consumption, GAS intend to transform society and respond to the challenges posed by global capital: from environmental depletion, to social injustice, to the fundamentally unfulfilling quality of "developed" lifestyles (Razeto 2002; Saroldi 2003).

My description is based mostly on participant observation over more than two years, from 2009 to 2011. My identity as a researcher was disclosed from the outset. I was a member of a Solidarity Purchase Group, participated in the yearly national GAS assembly, and became a delegate of my group in a nascent network of 62 GAS groups in the province of Bergamo, in Lombardy. During the latest phase of fieldwork I lent my professional competence to the planning of an updated census of Italian Solidarity Purchase Groups, with Bergamo as a pilot study (Forno, Grasseni and Signori 2013a). This research, titled Inside relational capital is an ongoing project led by CORES, the Research Group on Consumption, Networks and Practices of Sustainable Economies at Bergamo University (of which I am a co-founder). Its pilot phase led to a detailed picture of the GAS movement in the Bergamo area by the summer of 2012. Subsequently, it was extended to all the other provinces of the region of Lombardy and, beginning in 2013, to other Italian regions such as Sicily and Friuli/Venezia Giulia. Lombardy hosts the highest number of Solidarity Purchase Groups recorded so far (about 400), and about 7,100 gasista families (Forno, Grasseni and Signori 2013b). About $23 \%$ of them completed CORES's online questionnaire, and about two hundred respondents were coordinators of their respective groups. The survey asked detailed questions about membership, organization, motivation, and types of activity, but also gasistas' education, income, political orientation, and previous associative experience.

Mapping GAS membership and practices through a quantitative tool such as the CORES questionnaire provided me with a complementary lens for analyzing a movement that I had already observed and participated in for a couple of years. Moreover, a collaborative framework ensued between CORES and activists of the GAS network, as it became apparent that the GAS online census is not keeping up with the pace of their actual proliferation. Mapping GAS was thus also a way to meet the movement's need to chart its own boundaries. While social scientific methodology casts its objects of research with a language of "objective" analysis, ethnography is conscious about our role in participating in our own "objects" of observation. Such realization eschews the passive role of the subject or the "observed" and invites clearer commitments in terms of reciprocity and responsibility on the part of the researcher. Mapping meant charting boundaries, informing the movement's self-perception, and contributing to its agenda-setting (cf. St.Martin 2009). This in turn contributed to political action - politics being, at its best, a collective deliberation of the goals of a polis, namely a community.

In this paper I argue that GAS function as political-ecological networks, namely that Italian Solidarity Purchase Groups exercise an intentional politics of provisioning through a specific and original provisioning practice, which in turn is transformative of gasistas' lifestyles.

\section{Reinventing provisioning through economies of trust}

An apt example of the political as well as ecological aspects of GAS practice regards their attitude toward organic farming and organic certification. The CORES questionnaire provides clear answers as to the degree of gasistas' trust in the current systems of certification: of the 299 interviewed gasistas in Bergamo, 
only $19.3 \%$ trust organic food certification "a lot", while $41.4 \%$ trust fair trade certification "a lot" (Forno, Grasseni, and Signori 2013a: 61). ${ }^{5}$

Even though they don't trust certifications much, gasistas have a fairly good knowledge of certification logos. The Organic certification logo was identified correctly by $64.9 \%$ of the sample, the Fair Trade logo by 52.9\% and the Forest Stewardship Council logo by 57.2\% (Forno, Grasseni, and Signori 2013a: 61). A useful comparative benchmark is provided by a report on average styles of consumption in the municipality of Bergamo. In this study of 155 participants, more than 50\% went to a shopping mall for food and non-food purchases (Forno and Salvi 2012: 14). Some 41.3\% were concerned about health issues related to the food they bought, and 39.2\% with environmental issues. Yet $96.6 \%$ chose by price only (p. 16), and $76.8 \%$ had a high degree of trust for organic certification, 71\% for Fair Trade certification (p. 18). A further, image-based question nevertheless established that $60.5 \%$ claimed they did not know the Fair Trade logo (and a further $24.8 \%$ got it wrong), while 59.5\% claimed they did not know the organic certification logo (and a further $10.3 \%$ got it wrong). Again, while $75.7 \%$ of interviewees maintain that short supply chain foods offer a good quality/cost ratio and 75\% consider them tastier and environmentally friendlier, an insignificant minority actually buys them (p. 19).

What we can conclude from these eloquent data is that "income and awareness of the risks associated with certain styles of consumption are not sufficient to adopt new lifestyles that are more respectful of the environment and of one's health" (Forno and Salvi 2012: 21). In this section I am going to illustrate three examples of what I call here "economies of trust", all of which contribute to a growing literature on solidarity, affect, and regard as relevant factors in shaping economic relations even in the contemporary globalized world of advanced capitalism (Ash 2009; Bruni and Zamagni 2007; Hart et al. 2010), and which emerge as a result of social, environmental, and economic crises caused by neoliberal globalization, such as that experienced by the Latin American countries (Mance 2001) and more recently in Southern Europe. My first example will regard the use of participatory guarantee systems to certify the quality of farming products, specifically if organic, in a context of growing skepticism about the quality and quantity of information available to the consumer about food chains. The second example will regard solidarity purchase as an intentional act of support of specific producers in times of crises, which sets prices and logistics outside the laws of demand and offer. The third example profiles "co-production" as a relation of mutual support between producers and consumers that goes beyond the idea of capital investment and growth.

The survey data from 299 GAS in the province of Bergamo clearly supports the notion that Solidarity Purchase Groups prefer direct knowledge of the producers to certification systems, and organic certification is not a prerequisite for providers. When asked what are the most essential requirements for producers to do business with GAS, the statement most adhered to by Bergamo gasistas was: "GAS should buy only from producers who respect workers' rights" (79.9\%), and secondly "GAS should only buy from producers who present regular tax documentation" (68.9\%); while "GAS should only buy certified organic products" scored last (11.9\%) (Forno, Grasseni, and Signori 2013a: 62). Supporting self-certification amongst small farmers is one of the "scaling up" actions that networks of GAS, called Districts of Solidarity Economy (DES) are experimenting with in Lombardy. Instead of institutionalizing trust through a certification of standards, GAS producers and consumers are involved in collaboratively identifying a viable roadmap for "converting" to organic, or for keeping pesticides to a minimum.

The toxicity of post-industrial land, the loss of fertility in intensively farmed fields, the lack of phosphorus and potassium in insufficiently prepared soil, as well as the land-grabbing carried out by largescale certified organic agribusinesses, are all common concerns for these actors. A unique protocol of production is negotiated in each particular case. This idea, namely that of a "participatory guarantee system" (PGS) takes into account viable and local solutions to usually compromised scenarios, with nitrogen pollution in the soil from excessively fed cattle, or with infiltrations of industrial toxics in water collection

\footnotetext{
${ }^{5}$ The data used here are part of a wider research project, Dentro il Capitale delle Relazioni, carried out by the CORES Research Group under the scientific direction of Francesca Forno, Cristina Grasseni and Silvana Signori at Bergamo University (www.unibg.it/cores). The study was endorsed by the Italian Solidarity Economy Network (Tavolo RES www.retecosol.org) and carried out in collaboration with Davide Biolghini and Giuseppe Vergani of Tavolo RES.
} 
points. ${ }^{6}$ Rather than applying an abstract evaluation in the name of audit-like accountabilities (Strathern 2000), solidarity economy activists prefer to invite transparency from the producers about their actual hurdles, so that a protocol and a roadmap can be agreed upon collaboratively.

The implementation of this kind of project also marks a significant passage from "solidarity purchase" to the active construction of a "solidarity economy." In fact, GAS groups often provide membership and customers for Districts of Solidarity Economy (DES), but the transition from one organizational form (diffuse, self-organized purchase groups) to the other (concerted networks of GAS, producers, and associations or institutional actors) is not at all simple. There are currently 25 DES projects in Italy, compared with about one thousand registered Solidarity Purchase Groups. ${ }^{7}$ The participated guarantee system (PGS) project described above, for instance, is not being developed by individual Solidarity Purchase Groups (which would probably not have the agronomic and administrative competence to do so) but as a collaboration of three Lombard DES of the Varese, Como and Brianza areas.

Participatory certification can be read in part as a grassroots response to the muddle of national and European legislation on GM crops, which Les Levidow and Susan Carr have authoritatively described in their book as "a test to European Democracy" itself. Their GM Food on Trial recounts how, as the controversy on GM crops heightened, "...in 1999 several member states of the European Union collectively announced their refusal to consider any more approvals of new GM products", thus creating "...a procedural impasse, soon known as the de facto EU Council moratorium" (Levidow and Carr 2009: 3). Levidow and Carr stress how "...when the US government brought a WTO case against the 'illegal moratorium' and national bans on GM products, the EU was formally put on trial" (p. 256). This stalemate was largely the result of popular reactions to early EU agro-biotech policy, which had "granted safety approval for GM soya and maize, with no requirement for a special label on derived food products. GM grain was invisibly mixed in agro-food chains and processed food, so the public was cast as unwitting (and perhaps supportive) consumers of GM technology. Protesters warned that consumers would be human guinea pigs, being 'forcefed GM food'. By default of any clear means to act as citizens, many consumers 'voted' against GM food through their purchases and protest" (p. 11).

Debate over GM labeling, traceability and detectability is still open in Europe. Strict labeling requirements were announced for all food and animal feed products linked in any way to transgenic crops (Mitchell 2003), but the definition itself of GM for the purpose of labeling is an ongoing object of controversy (Levidow and Carr 2009: 189-217). A turning point in Italian public opinion came when the European Commission sought to lift Italy's national ban on several GM foods and fodders such as maize, soya, and rapeseed. At that point it was clear that the nation-wide protectionist attitude was inadequate for preserving a GM-free Italian agricultural sector.

In the face of this complex scenario, GAS food activists act on the premise that the only guarantee of real traceability consists in personal intervention in the food chain. Rather than counting on top-down surveillance through either GM labeling or organic certification, GAS establish an acceptable degree of transparency by engaging in collaboration with the producers. For instance, in my work with the Bergamo "producers' mapping group," we sought to share and compare data on our current providers and scout new local farmers and breeders to convince them to enter a partnership with GAS. We contacted potential providers and proposed soya- and maize-free dietary protocols for their cattle and pigs. Our group leader was adamant that "all soya is GM anyhow", and asked GAS providers to avoid it in exchange for higher prices and trusted customers. Our formula was clear and practice-driven: know your farmer, make your demands explicit, negotiate what is reasonable to achieve within a roadmap of "conversion to organic", and reward the

\footnotetext{
${ }_{6}$ Michele Corti, professor of animal husbandry at Milan's State University, and Silvia Contessi, Ph.D. student at Bergamo University, are analyzing such systems in their making (see the EUPOLIS research Heritage localized agrifood systems HeLAFS as a specialized dimension of LAFS (2012/2013), http://www.eupolis.regione.lombardia.it/shared/ccurl/189/606/10_Le_politiche_03.pdf. Last accessed March 62013.

${ }^{7}$ On October 23, 2012, the national network of Gruppi di Acquisto Solidale (GAS) registered 900 Solidarity Purchase Groups http://www.retegas.org/index.php?module=pagesetter\&func=viewpub\&tid=2\&pid=7. There are currently 25 Districts of Solidarity Economy, 7 of which located in Lombardy. They are listed on http://www.retecosol.org/modules.php?op=modload\&name=Sections\&file=index\&req=listarticles\&secid=2 2 .
} 
producer through direct transactions and higher prices. A successful example was a female cow breeder whom we visited and promised to buy meat from, on the condition that she would eliminate soya from fodder. Our support helped her finance herself while obtaining a license for a butcher shop that she had been struggling to establish in the nearby village.

Solidarity does not only involve agricultural "conversions." A second example was prompted by the two earthquakes that shook Italy in L'Aquila in 2009 and Modena in 2011. In this case, solidarity took the pragmatic form of buying damaged produce from the earthquake-affected Parmesan dairies, not at fire-sale prices but as a form of support to the affected producers. Through mailing lists and Facebook pages, hundreds of gasistas bought tons of damaged Parmesan from the quake-affected dairies; this network quickly collected group orders so that cash could flow to the region and produce could be salvaged before it spoiled (Modena is about two hours drive from Bergamo, and collective orders would be collected in person by gasistas with their personal means of transport). ${ }^{8}$ In the case of Abruzzo, the idea of acquiring Christmas gift packages from Abruzzese farmers came after one of Bergamo's gasistas spent a solidarity-driven eco-tourism holiday in an area affected by the earthquake. Upon her return, she circulated a list of Christmas Packages (of local products such as cheese, salami, and preserves) to the Bergamo GAS network, proposing to buy them from a network of Abruzzese farms. This project, sponsored in Abruzzo by a local Catholic Association and an Agricultural and Conservation Park, and in Bergamo by ReteGasBergamo, raised 11,000 Euros (US $\$ 15,000)$ thanks to the volunteer who initiated and coordinated the collective order.

A third example is provided by a family dairy, Tomasoni, which was salvaged from bankruptcy in 2009 by a network of 200 Solidarity Purchase Groups. The firm started doing business with GAS in 2002, "converted" to organic in 2004, and began having financial trouble in 2008. In 2009, as a result of the credit crunch, the factory was about to close, and sent a request for help to its gasistas. Tomasoni customers and other GAS raised an interest-free, 18-month loan of about 150,000 euros within 45 days. This was enough to pay standing bills and keep Tomasoni alive, and since then the dairy almost exclusively supplies GAS, which in turn accept higher prices.

This happens in a context where intensive farming and large dairy concerns are the norm. Lombardy's milk production is $40 \%$ of Italian national production and averages 4.3 million tons a year. It employs six thousand enterprises and twelve thousand people (plus four hundred packaging and transformation plants). Eighty percent of Lombard milk is transformed into cheese for about 1.5 billion euros (generating $23 \%$ of the regional agricultural income), $40 \%$ of cheese produced in the region is protected by geographical indication (the EU Protected Denomination of Origin) and uses about 50\% of the milk transformed. ${ }^{9}$ In this context, small-scale raw milk and cheese producers are especially burdened by the high costs of logistics and by milk's low market price (about 33c/l).

Selling to a Solidarity Purchase Group can ease economic pressure on small producers, bring immediate relief in case of catastrophic events, and transform and support the ecological management of family enterprises. The Tomasoni case in particular creates a significant precedent: the firm did not turn into a cooperative, nor are the funders organised into an association, nor is this a form of socially responsible "investment". Instead, I propose to view it as a new form of "economy of trust" (Sage 2007) that gasistas call "co-production", not because the functional roles of producers and consumers somehow merge but because reciprocal knowledge generates loyalty, strengthens relationships and, thus, creates economic resilience. The idea of trust couples with that of solidarity; in fact it is a condition for solidarity. It shortens the distance between producer and consumer, sometimes literally, and encourages people to avoid too many intermediaries. Similar to family bonding relations, and especially in a context of general breakdown of trust in institutions such as banks, the state, and quality guarantors, confidence is established on the basis of

\footnotetext{
8 See http://www.ecquologia.com/cms/index.php?option=com_content\&view=article\&id=756:gli-italiani-hanno-decisodi-risollevvarsi-da-soli--liniziativa-del-parmigiano-solidale-corre-sul-web\&catid=20:territorio.

${ }^{9}$ Data circulated at the conference "There’s ferment in milk" in February 2010 by Lecco's Chamber of Commerce at the fair Ristorexpo. The conference aimed to sensitize professional restaurant operators toward using shorter milk and dairy chains, thus reviving local cheese production. Speakers: Cristina Grasseni, Hansi Baumgartner, Giovanni Guadagno, Matteo Scibilia.
} 
proximity and direct collaboration, as widely reviewed in the anthropology of kinship, particularly among entrepreneurial families and extended families (Lomnitz and Pérez-Lizaur, 1987, p. 118; Schneider and Schneider, 1976).

The Tomasoni case was studied by business economist Silvana Signori, who surveyed the 200 Solidarity Purchase Groups involved in the rescue operation and received 244 valid or complete answers from its members, 169 of which had agreed to join the financing operation. Significantly, only nine of these gasistas had pledged a sizeable sum (more than 500 Euro), while most had contributed between 50 and 100 Euro. Asked about their motivation, the desire to continue to consume Tomasoni's products was mentioned by only 5 respondents, even if 32 (about 19\%) expressed appreciation for product quality (Signori 2010). Obviously this was not a behavior induced solely by appreciation of product quality. Seventy gasistas (out of 169) referred instead to "the desire to participate", "to be an active part of a bigger system", "to have the possibility to do something important", "to collaborate" and "to provide an alternative". Fifty-nine answers evoked the concept of "solidarity", as in the "S" of the acronym "GAS" (Signori 2010).

None of the examples described above is considered by gasistas to be an explicitly anti-capitalist manoeuvre. In fact, all of these interventions aimed at keeping someone "in business". What they introduced was, on the one hand, a non-oppositional rapport with the producers, whereby the consumers' advantage is not construed as an erosion of the producers' profit. Quite the contrary, co-producing consumers provide a non-capitalocentric value framework (Gibson-Graham 2006) to assess product quality (for instance, organic but not certified), economic sustainability (for instance, lending money at no cost or buying at higher price) and ecologic sustainability (for instance, encouraging low-pesticide farming and local supply chains). Any of these examples can be easily misconstrued as anti-economic activities: Tomasoni, in fact, ran into bankruptcy after scaling down the entire business to opt for an all-organic line of production. The Abruzzese smallholders were supported by an agricultural and conservation park. And the cattle breeder in Bergamo was operating in an environmental park situated in a hilly area, unsuitable for large and intensive breeding. Nevertheless, the apparent unsustainability of these operations can be disproved given that price-setting is not considered a mere function of the dynamics of cutting costs for higher profit or of self-adjusting demand and supply.

In a full-length monograph I explain how collective consumption through GAS enables multiple layers of new economic circuits that are explicitly inspired by the principle of solidarity. In particular, while the individual GAS group is mostly concerned with food provisioning and has a limited impact on local economies, networks of GAS provide organized and dedicated "networks of networks" that support "citizenship markets", renewable energy provision, short supply chains, and even forms of solidarity-based dental insurance (Grasseni 2013).

\section{Solidarity purchase groups as political-ecological networks}

A great deal of time and passion are invested in gasistas' discussions of preferences and criteria to contact a farmer, accepting another's commercial proposition, or terminating a partnership. The absolute preference usually goes for supporting local small-scale farmers. Vegetables and fruit are usually found locally, and increasingly so too are meat and dairies. A certain number of cheese and milk retailers have switched their entire business to organic in order to provide GAS groups and networks on a regional basis (for instance, throughout Lombardy ${ }^{10}$ ). In my knowledge, a few trusted cooperatives - some local, some located further away in Tuscany, Trentino and Sicily - provide the GAS of the Bergamo province with olive oil, oranges, and minimally processed foodstuffs such as pasta, tomato sauces, jam, and fruit juices. Wine is increasingly entering the equation, as well as fresh fish, but also clothes, shoes, and personal hygiene items.

It is not easy to create a comprehensive network of proximal food providers whose foodstuffs are traceable both in terms of quality and respect for workers' rights. In fact, new "budding" GAS may be dependent on established relationships with providers of longer-standing purchase groups (especially

\footnotetext{
${ }^{10}$ Lombardy includes 11provinces over about 9,200 square miles, an extension comparable to that of Massachusetts (about 10,500 sq mi).
} 
agricultural cooperatives) as no real alternative can be found on the market. As GAS proliferate, though, they find new partners nationwide. For instance, some GAS buy from agricultural cooperatives working Sicilian lands that have been expropriated from the Mafia (Forno and Gunnarson 2010). Since 2011, a fruitful collaboration has ensued between networks of Northern Italian Solidarity Purchase Groups and an "archipelago" of Sicilian orange growers, Arcipelago Siqillyah (www.siqillyah.com). The latter organize orange "landings" in as many Italian market squares as GAS groups can arrange for them, to sell their oranges directly and to meet their customers. This obviously requires organization, costs, and labor on both parts: to arrange transport and delivery, parking, and stands for the market. Most of the oranges are pre-sold to the local Solidarity Purchase Groups, who guarantee collective orders - the rest goes to promotion, public visibility, and on-the-spot retail.

In October 2012, national television and the press reported that up to 7 million Italians allegedly practice forms of solidarity economies (Rubino 2012). Building on about ten years of research on the relocalization of food systems in Italy and on two years of ethnography with the Italian solidarity economy network, I would suggest that up to seven million Italians may well be practicing forms of collective purchase, but that only a conservative estimate of about 100,000 people do so specifically in the name of solidarity, and thus make this practice political. This narrow framing of solidarity economy allows me to distinguish it from any kind of collective economic action, such as purchase groups and buying coops, that are dictated uniquely by price considerations and by a (legitimate) effort to obtain the best quality and the highest quantity for the lowest price. My construction of solidarity economy as a (narrowly defined) political practice is based on the idea that solidarity purchase groups are driven by additional motives, such as those outlined in the three examples illustrated above: to make farming a more ecologically sound practice, to weave relations of proximity with farmers, and to take an active role in re-engineering food systems through co-production.

The figure of 100,000 people is based on quantitative data gathered through a survey of northern Italy's Solidarity Purchase Groups carried out at Bergamo University, and on projections that we estimated together with representative of the nationwide working group on Districts of Solidarity Economy (Tavolo RES), on the basis of their current national census of GAS groups. The current GAS on-line census registers about 800 groups in the whole of Italy, a nation of about 60 million inhabitants, but when I participated in the mapping of the active GAS groups in the province of Bergamo in 2011, we listed more than 60 groups over a province of just one million inhabitants. This led us to believe that the GAS expansion might have been momentous, practically hidden from view, and not charted in the last 5 years of economic crisis - which in Italy has been accompanied by a crisis in political representation. ${ }^{11}$

In my research experience, GAS adherents come from all walks of life: I met civil servants, factory workers, professionals with young families, retired people, and students. Their statistical profile locates them clearly among the well-educated Italian lower middle classes, mainly employed in poorly paid but secure jobs in education or in the public service sector: of the 1658 gasistas interviewed by CORES throughout Lombardy by the end of 2012, 62\% were female, 49.6\% were aged between 30 and 44 years and another 42,9\% were aged between 45 and $60.49 .5 \%$ had a BA degree (of which and $37.6 \%$ had a higher degree) and $71,8 \%$ were families with children (25,6\% of which younger than 5 ). $60 \%$ worked in clerical or teaching jobs, whilst only 4,4\% were factory workers. Regarding their family income, 22,3\% reported a net monthly family income inferior to 2,000 Euros, and 56\% had between 2,000 and 3,600 Euro ( Forno, Grasseni and Signori 2013b).

Now, a family of four living on a monthly income of maximum 3,600 Euros (roughly 4,700\$) in northern Italy (where car petrol costs about 10 dollars to the gallon) hardly fits the stereotype of the wealthy bourgeois or the radical chic. These people depend on clerical salaries, send their children to public school, and may be able to afford one car, especially if they are servicing a mortgage at the same time. Paul Ginsborg

\footnotetext{
11 For instance, the 2011-2012 Monti government did not include parliamentary representatives but functionaries, bankers, and administrators. It was sworn in directly by the President of the Republic in March 2012, to find "technical" and "apolitical" solutions to the economic crisis that was nearly bankrupting the country under Berlusconi's resigning government. Democratic elections were called in February 2013.
} 
(2010) offers the definition of a "reflexive middle class" - namely a lower middle class that uses education and relational capital as a resource to act in favor of civic solidarity and social cohesion, despite having little voice in economic strategies and political decision-making. Usually, this class acts on the premise of moderately left-wing dispositions, usually inherited either from the socially oriented fringes of the now defunct Christian Democrat Party, or from the post-communist Democratic Party. The lifestyle of this lower middle class is indeed very distant from a numerically limited higher middle class with high-end consumption lifestyles, conservative political propensities, and little disposition to social responsibility.

GAS membership as currently organized is unattractive to the poorest, who would be unable to support farmers through advance payments and higher prices. But it is not a middle class club, either. A 50 to 100 Euro loan to Tomasoni is, for a gasista family, a significant effort. Travel expenses to pick up produce from the most distant producers with one's personal car were meticulously documented and reimbursed to the penny. Price, and not only solidarity, was always discussed at length in my own GAS: once, when a "product referent" for berries and red fruits hazarded offering a 1 Euro per kilo increase to a local provider, she was harshly critiqued in assembly. It was clear to me that at least the families in my group were not just engaged in a moral struggle to consume ethically: they were also struggling to make ends meet. One of us had to leave the group, with the adamant explanation that she could no longer afford solidarity-driven purchase standards.

A quick comparison with Slow Food may help illustrate the fundamental social difference between two types of food activism that might, at first sight, look and sound similar. In the Bergamo area, in fact, there exists a long-standing co-operation between Slow Food and GAS activism. For instance, in 2010 the Slow Food Condotta (Chapter) of the Valli Orobiche (Bergamo's valleys) promoted the adoption of zero-mile menus and sponsored the use of local red maize in its affiliated restaurants. Under the leadership of the same person, now Slow Food "governor" for Lombardy, Terra Madre Lombardia proceeded to organize seminars on "permaculture", "biodiversity", "food waste", and "land as a commons". In 2012, these seminars showcased, among others, a project for short chain supply of bread, Spiga and Madia, developed by a District of Solidarity Economy in Brianza, near Milan. This was hailed as a benchmark of "zero-mile democracy": not only a re-territorialization of food production (reintroducing local varieties of wheat, using local mills, and including a network of local bakers to serve more than 500 families), but one done in the name of food sovereignty (De Santis 2010).

This is an example of "parallel convergence" so to speak, between different types of food activism that may well support the same agenda (and even the same farmers) but have traditionally appealed to customers of different socio-economic status through distinct provisioning styles - gasistas generally being more price-aware and lower-middle class than Slow Food "foodies". While Slow Food organized zero-mile restaurant menus and supported the reintroduction of a local variety of red maize of the Bergamasque valleys, Bergamo's gasistas attempted to re-engineer the entire food chain, not only protecting that one "niche" cultivar, but "converting" the farmer to rotate this grain with plain organic potatoes, which they would buy at preferential prices. In other words, gasistas were committed to transforming the entire supply chain, not just to promote a niche territorial product.

Styles of participation are also of paramount importance. Gasistas often begrudge the lack of sobriety in "foodies" consumption choices and lifestyles. An organizer of the Spiga and Madia project, for instance, mentioned that local Slow Food members would be more interested to Barolo vertical tastings than in buying much cheaper "panettone" Christmas cakes produced by the local bakes. Again, when Carlo Petrini publicly presented his book Buono, Pulito e Giusto in Bergamo 2010, rumor had it amongst gasistas that the GAS network did not officially partake in the event because sponsoring associations were invited to promote the sale of the book. With their stern focus on volunteered participation, sobriety, and reduction of consumption, gasistas often come across as ascetic visionaries (Osti 2006), setting themselves far apart from self-indulging "foodosophers" (gastrosofi gaudenti, Berlendis 2009). Whilst the latter support the world peasantry because they draw the consequences of a universal "right to pleasure" (Slow Food Italia 2010), Solidarity Purchase Groups and Solidarity Economy Districts root themselves in a culture of voluntary simplicity, a critique of consumerism, and awareness of the ecological and political implications of mass provisioning (Grasseni 2013). 
Not being representative of the most disenfranchised sectors of society does leave gasistas in an ambivalent and unresolved position vis-à-vis the issue of social inclusion and equity. Nevertheless, their contribution consists in striving to maintain or re-suturing a viable provisioning fabric that includes smallholders, corner shops, and a farmed local landscape, rather than allowing gentrified neighborhoods to turn into urban food-deserts. Solidarity Purchase Groups have numerous facets, which we do not have the space to analyze here (see Grasseni 2013 and 2014). At the individual level (the single GAS group operating for the benefit of its membership), they could be considered both as a self-help association (securing quality food at affordable prices). At the network level, though, they are capable of significant intervention in the face of ecological and financial crisis. For instance, after the 2009 quake in Abruzzo, retegas.org called the annual nationwide GAS assembly in L'Aquila, to bring concrete solidarity to the local farmers and residents. The assembly took place in an encampment outside the medieval town, and gasistas camped or stayed at local bed and breakfasts, hotels or agro-tourism sites, bringing business to the local economy. ${ }^{12}$

In effect, GAS are much more a form of political-ecological network than they are "alternative food networks", which have stirred much critical consideration because of their proneness to localism and elitism (Goodman, DuPuis, Goodman, 2012; Whatmore, Stassart, Renting 2003). Firstly, gasistas reach beyond "alternative" provisioning and set themselves a goal, that of solidarity with the farmers and the environment. They thus exercise an intentional politics of provisioning. Secondly, through their provisioning practice, GAS aim to be transformative of lifestyles. Though dealing mostly with food provisioning, they reconfigure food from what are commonly conceptualized as formal transactions involving foodstuff as commodity, or as objects of individual taste and distinction, to restore it to its dimension of mutual relationality and ecological embeddedness (Mauss 1924, Polanyi 1968, Gudeman 2012). In GAS practice, food provisioning has to do with re-appropriating local knowledge and agency: from knowing seasonality, to knowing how to pluck a chicken; from knowing what grows well in one's specific farming landscape, to knowing who actually farms there. According to the CORES survey, nearly 83\% of Bergamo gasistas had increased their intake of organic food and almost $80 \%$ were consuming more local foodstuffs since they joined a GAS. Additionally, $27.6 \%$ had introduced environment-friendly detergents, more that $40 \%$ had begun avoiding supermarket shopping altogether, and just as many had begun producing certain foods, such as bread, by themselves. Almost 24\% had begun to get more involved in issues regarding their municipality and more than $40 \%$ found that they were behaving in a more cooperative way. More than $27 \%$ felt that they were more capable of influencing politics (Forno, Grasseni, and Signori 2013a: 69-71). Clearly, being an active gasista engages one not only in alternative food consumption, but also in a much broader and deeper form of ethical and political deliberation about the economy.

\section{Conclusion: building knowledge and economies of trust through co-production}

When we think of Italian families sharing food, we may think of the Mediterranean diet, of family meals, maybe of Slow Food, but other forms of collective and still largely family-based foodways are being experimented with in contemporary Italy. GAS practice never ceases to be about "purchase", but at the same time it aims to affect politics and economics through direct access to producers. A painstaking work of collective deliberation and logistics underscores their provisioning practice. One can see the practical disadvantages: as one fellow gasista once said, "I explained what we do to a friend and she commented 'my God you take a whole year to do the weekly shopping'!" Though time consuming, GAS deliberation about how to put solidarity in practice amounts to political literacy-building. The principle of solidarity is explicitly invoked in the groups' meetings, both in the individual solidarity purchase group, and at the level of national assembly. At both levels, a principle of consensus-building is followed or at least invoked. GAS activists believe that they exert an innovative impact on local economic contexts, a transformative action, which in turns reinvents the relationship between producers and consumers. It is a process that entails subjective, collective, and procedural changes. The reciprocal listening of consumers and producers through repeated

\footnotetext{
12 http://www.ilcambiamento.it/chilometro_zero/sbarco_gas_laquila_2011.html
} 
visits builds an economy of trust, allowing producers and consumers to achieve their goals ethically not by exiting the market but rather by accessing it on one's own terms - as in the Tomasoni case.

Gasistas do not necessarily view themselves as attempting to build non-capitalist economies, but they introduce a paramount dimension of affect and of "regard" (Offer 1997; Sage 2007) in economic transactions, which has been underlined in Gibson-Graham's "diverse economy" framework (Gibson-Graham 2008; Burke and Shear 2014). They use a loose definition of solidarity economy that emerges from the French, Portuguese, and Italian literature on global justice (Laville 1994; Mance 2001; Saroldi 2003) and has established itself as a cross-disciplinary notion (Ash 2009; Hart, Laville and Cattani 2010). This works as an umbrella concept spanning diverse social networks that reinvent consumption as "political consumerism" (Micheletti 2003), "ethical consumption" (Carrier and Luetchford 2011), "community economies" (GibsonGraham 2006), or "civic economies" (Bruni and Zamagni 2007). This interdisciplinary literature has borrowed the notion of "co-production" from science and technology studies (Jasanoff 2006), rural sociology (van der Ploeg and Marsden 2004), and feminist geography (Gibson-Graham 2006) to describe the concurrent emergence of the social, the material and the natural. The notion of co-production describes this dynamic notion of mutual relationship. It leaves "producers" to do their job, but it casts GAS activists as supporters for producers' primary activity. A proximal farming environment is also "co-produced" by consumer/producer collaboration and transactions. According to Dutch rural sociologist van der Ploeg, in coproduction both natural and social resources are co-constituted (Van der Ploeg and Marsden 2004): thus both local agronomic knowledge and composting soil are "co-produced" (van der Ploeg 2006: 200).

Co-production is also practiced by gasistas as a space for consensus building, namely as an ongoing conversation nurtured by frequent correspondence and visits to the farmers, who should be "accompanied", "supported", and "converted". GAS practice is baffling at many levels, as activists are not usually associated in formal cooperatives, but distribute goods and services on a volunteer basis. Beyond their sometimesdismissive gloss as yet another guise of "alternative food networks", GAS are a prime anthropological object as they aim to re-embed economy and politics into a social and relational fabric. These collective experiments engage with and rethink the issue of "distribution", both in terms of logistics and in terms of the economic relationship between producer and consumer. The most obvious way in which Gasistas engage in distribution lies at the very core of GAS practice. Each one of them procures orders of one specific product from a trusted provider, then each collects one's order and pays up one's dues. Each member of the GAS does this in turn, thus sharing the burden of liaising with the provider, collecting the bulk produce, paying up on behalf of everyone, storing the products, and inviting the others to collect their share. There is no overhead, or "buying costs", as there is no room in GAS for "just buying". If a member "just buys", and does not participate in meetings, or does not volunteer for taking up the logistics of one product, she is reminded of the duty of reciprocity and may finally find herself "pruned" from the mailing list.

Italy's Solidarity Purchase Groups reconnect the crisis-affected lower-middle class with a smallholder agriculture that still employed $42 \%$ of the population as late as 1951 . They secure quality food at relatively advantageous prices for themselves and their friends and families - produce of freshness and quality that one would expect to find at farmers' markets or high-end supermarkets. They thus solve in a very effective way a growing problem of food security that the current financial and ecologic crisis has induced (that is, if by food security we mean security of access to healthy food, thus adding an important element of self-determination and of food sovereignty to the common understanding of food security as access to what food is sufficient for bare survival, regardless of health, quality, freshness, or pleasure). GAS practice can thus be read as a new form of mutualism in the face of failing trust in the market as "neutral" mechanism for price determination, and in agribusiness as food provider. Gasistas' direct relationship with their producers, for instance, redistributes risk. Risks from soil and water contamination, or from untraced GM nutrients, are managed through direct arrangements and viable roadmaps to organic farming.

In conclusion, GAS are an important case of citizens freely entering cooperative relationships between themselves and with farmers and food producers, aiming for reciprocal benefit on a concrete basis while charting new economies and ecologies of trust. In the Italian smallholders scenario, GAS play an increasingly important role in offering a survival opportunity to small farms, as they recruit them to 
reconstruct local food chains, while shielding these often family-run entrepreneurs from the worst effects of the financial crisis. GAS activism in the wake of the recent earthquakes in Southern and Northern Italy (April 2009, May 2012) as well as the credit crunch begun in 2008 offer concrete examples of how forms of selforganized solidarity can sustain local economies in times of worsening environmental and economic crises. In this respect, GAS differ from other alternative food networks, especially as they move beyond mere food provisioning to face issues of "solidarity based" interventions in compromised territories and economies. At the grassroots level, they display the ambition to map producers, to coordinate larger networks, to initiate or support projects in post-earthquake areas or with marginal rural producers. They cooperate with different agencies such as Slow Food with its focus on food heritage, or the Catholic farmers' unions intervention in post-quake farming areas.

\section{References}

Amin, A. (ed.) 2009. The social economy: international perspectives on economic solidarity. London: Zed Books.

Berlendis, L. 2009. Un nuovo patto con la terra. In C. Grasseni, M. Messina and M. Salomone (eds.) La reinvenzione del cibo, special issue of Culture della sostenibilità, 6: 137-146.

Bruni, L., S. Zamagni. 2007. Civil economy: efficiency, equity, public happiness. Bern: Peter Lang Publisher.

Burke B.J. and B.W. Shear. 2014. Introduction: engaged scholarship for non-capitalist political ecologies. Journal of Political Ecology 21: 127-144.

Carrier, J. and P. Luetchford. (eds.) 2012. Ethical consumption: social value and economic practice. Oxford: Berghahn Books.

Castells, M. and A. Portes. 1989. World underneath: the origins, dynamics, and effects of the informal economy. In A. Portes et al. (eds.) The informal economy: studies in advanced and less developed countries. Johns Hopkins University Press.

DeLind, L. 1999. Close encounters with a CSA: the reflections of a bruised and somewhat wiser anthropologist. Agriculture and Human Values 16(3): 3-9.

. 2002. Place, work, and civic agriculture: common fields for cultivation. Agriculture and Human Values 19: 217-224.

De Santis, G. 2010. Spiga and madia. In R.E.S. Tavolo (ed.) Il capitale delle relazioni. Come creare e organizzare gruppi d'acquisto e altre reti di economia solidale. Milano: Altraeconomia Edizioni. Pp. 94-98.

Forno, F., C. Grasseni and S. Signori. 2013a. Dentro il capitale delle relazioni: Provincia di Bergamo. Indagine Osservatorio CORES e Tavolo Nazionale RES. CORES - Working Paper Series 1.

. 2013b. Dentro il capitale delle relazioni. In D. Biolghini (ed.) Un'economia nuova, dai Gas alla zeta. Milano, Altraeconomia, pp. 12-48.

Forno, F. and C. Gunnarson. 2010. Everyday shopping to fight the Mafia in Italy. In M. Micheletti and A.S. McFarland (eds.). Creative participation: responsibility-taking in the political world. Boulder: Paradigm Publishers. Pp.103-126. $\underline{\mathrm{draft}}$

Forno, F. and S. Salvi. 2012. Per una cittadinanza sostenibile: analisi critica dei consumi delle famiglie di Bergamo. Comune di Bergamo and Cittadinanza Sostenibile.

Gesualdi, F. 1990. Lettera a un consumatore del nord. Bologna: EMI.

Gibson-Graham, J.K. 2006. A post-capitalist politics. Minneapolis: University of Minnesota Press.

Gibson-Graham, J.K. 2008. Diverse economies: performative practices for 'other worlds'. Progress in Human Geography 32: 613-632.

Ginsborg, P. 2010. Salviamo l'Italia. Torino: Einaudi.

Goodman, D., M. DuPuis and M. Goodman. 2012. Alternative food networks: knowledge, practice, and politics. New York: Routledge. 
Grasseni, C. 2011. Re-inventing food: Alpine cheese in the age of global heritage. Anthropology of Food [Online] 8.

Grasseni, C. 2012. Developing cheese at the foot of the Alps. In E. Finnis (ed.) Re-imagining marginalized foods. Tucson: University of Arizona Press. Pp. 133-155.

Grasseni, C. 2013. Beyond alternative food networks: Italy's Solidarity Purchase Groups. London: Bloomsbury.

Grasseni, C. 2014. Food activism in Italy as an anthropology of direct democracy. Anthropological Journal of European Cultures, forthcoming.

Gudeman, S. 2012. Economy's tension: the dialectics of community and market. Oxford: Berghahn Books.

Hart, K., J-L. Laville and A.D. Cattani (eds.). 2010. The human economy: a citizen's guide. Cambridge: Polity Press. Ch. 1.

Hinrichs, C. 2003. The practice and politics of food system localization. Journal of Rural Studies 19: 33-45. draft

Hinrichs, C. and T. Lyson. 2009. Remaking the North American food system: strategies for sustainability. Lincoln: University of Nebraska Press.

Jasanoff, S. 2006. States of knowledge: the co-production of science and the social order. London: Routledge. Ch.2

L'Eco di Bergamo. 2012. Gruppi di Acquisto Solidale. Bergamo ne studia l'esperienza. L'Eco di Bergamo, September 12, 2012. Unsigned article in the Economy section of Bergamo's local newspaper, available online at http://www.ecodibergamo.it/stories/Economia/313482_gas/ (last accessed December 29, 2012).

Lamine C. and N. Perrot. 2006. Les AMAP: un nouveau pacte entre producteurs et consommateurs? Gap: Éditions Yves Michel.

Laville, J-L. 1994. L'Economie solidaire. Paris: Descleé de Brouwer.

Levidow, L. and S. Carr. 2009. GM food on trial: testing European democracy. New York: Routledge.

Lomnitz, L.A. and M. Pérez-Lizaur. 1987. A Mexican elite family, 1820-1980: kinship, class, and culture. Princeton, NJ: Princeton University Press.

Mance, E. 2001. A revoluçãao das redes: a colaboração solidária come uma alternativa pós-capitalista à globalização atual. Petròpolis: Editora Vozes.

Martinez-Alier J., Anguelovski I., Bond P., Del Bene D., Demaria F., Gerber J.-F., Greyl L., Haas W., Healy H., Marín-Burgos V., Ojo G., Porto M., Rijnhout L., Rodríguez-Labajos B., Spangenberg J., Temper L., Warlenius R. and I. Yánez. 2014. Between activism and science: grassroots concepts for sustainability coined by Environmental Justice Organizations. Journal of Political Ecology 21: 19-60.

Mauss, M. 1924. Essai sur le don. English translation 1954. The gift: the form and reason for exchange in archaic societies. 9th Edition, 2000. New York: W. Norton and Company.

Micheletti, M. 2003. Political virtue and shopping: individuals, consumerism and collective action. Basingstoke: Palgrave Macmillan.

Offer, A. 1997. Between the gift and the market: the economy of regard. Economic History Review 50(3): 450-476.

Osti, F. 2006. Nuovi asceti: consumatori, imprese e istituzioni di fronte alla crisi ambientale. Bologna: Il Mulino.

Petrini, C. 2007. Slow food nation: why our food should be good, clean, and fair. Rizzoli.

Polanyi, K. 1968. Primitive, archaic, and modern economies. Essays of Karl Polanyi. George Dalton (ed.). New York: Anchor Books.

Razeto, L. 2002. Las empresas alternativas. Montevideo: NORDAM.

Roelvink, G. 2010. Collective action and the politics of affect. Emotion, Space and Society 3(2): 111-118. 
Rubino, M. 2012. Spesa di gruppo, è boom. 7 milioni di Italiani nei "Gas", La Repubblica online, October 29, 2012.

http://www.repubblica.it/economia/2012/10/29/news/spesa_di_gruppo_boom_7_milioni_di_italiani$\underline{45427020}$ last accessed October 31, 2012

Sage, C. 2007. Trust in markets: economies of regard and spaces of contestation in alternative food networks. In J. Cross and A. Morales (eds.) Street entrepreneurs: people, place and politics in local and global perspective. London: Routledge. Pp. 147-163.

Saroldi, A. 2001 Gruppi di Acquisto Solidali: guida al consumo locale. Bologna: EMI. . 2003. Costruire economie solidali. Bologna: Editrice Missionaria Italiana.

Schneider, J. and P. Schneider. 1976. Culture and political economy in Western Sicily. New York: Academic Publishing.

Signori, S. 2010. Exploring ethical investors' motivations: the case of the Tomasoni Organic Dairy. Paper presented at the 16th International Symposium on Ethics, Business and Society, IESE Business School, May $13^{\text {th }}-15^{\text {th }}, 2010$, Barcelona.

Siniscalchi, V. 2013. Environment, regulation and the moral economy of food in the Slow Food movement. Journal of Political Ecology 20: 295-305.

Slow Food Italia. 2010. Le conseguenze del piacere. Documento del Congresso 2010-2014. San Mauro Torinese: Stargrafica.

St. Martin, K. 2009. Toward a cartography of the commons: constituting the political and economic possibilities of place. Professional Geographer 61 (4): 493-507.

Strathern, M. (ed.) 2000. Audit cultures. New York: Routledge.

Tavolo, R.E.S. per la Rete Italiana di Economia Solidale 2010. Il Capitale delle relazioni. Come creare e organizzare gruppi d'acquisto e altre reti di economia solidale. Altraeconomia Edizioni.

Van der Ploeg, J.D. 2006. Oltre la modernizzazione: processi di sviluppo rurale in Europa. Soveria Mannelli: Rubettino.

Van der Ploeg, J.D. and T. Marsden (eds.) 2008. Unfolding webs: the dynamics of regional rural development. Assen: Van Gorcum Publishers.

Whatmore, S., P. Stassart and H. Renting. 2003. What's alternative about alternative food networks? Environment and Planning A 35(3): 389-397. 